\title{
The Effect of Incentive System on Job Performance Motivation as Mediator for Public Sector Organization in Uae
}

\author{
Universiti Tun Hussein on Malaysia (UTHM) \\ Universiti Tun Hussein on Malaysia (UTHM) \\ Universiti Tun Hussein on Malaysia (UTHM) \\ *Corresponding author E-mail: fadillah@uthm.edu.my
}

Rashid Ahmed Khamis Al Naqbi PROF. Dr. Rosman Bin Md Yusoff Dr. Fadillah Binti Ismail

\begin{abstract}
The main purpose of this research is to study the effect of motivation and incentive system on the job performance of public sector employees in UAE. The details of this research will be provided in an attempt to validate whether incentives have a potential effect on motivating employee and enhance job performance in the public sector. The purpose of the research is also to illustrate to what extent incentives are used in the UAE's public service sector. To fulfill the objective of the research as well as to obtain real and reliable data, a research study will be conducted at was conducted at the Economic Development Department (EDD) in Al Sharjah. This research has adopted a quantitative approach to assess the effect of the incentive system in public sector in UAE on the job performance, and to identify the mediating effect of employees' motivation in two dimensions (intrinsic and extrinsic) on the relationship between the incentive systems (monetary and tangible and non-monetary and intangible), and employees' performance. The research method will quantitatively analyze the structured questioner's data using a statistical approach. On completion of the qualitative research, it is expected that the findings will concur with the consensus of the findings in the literature review. The data analysis will prove that there is a significant relation between incentives in the form of rewards and recognition and better work performance. This research study, hopes to determine whether most of the public employees in the abovementioned organisation are motivated by the financial and non-financial incentives and are encouraged and motivated towards greater work performance.
\end{abstract}

Keywords: UAE, Motivation, Financial Incentives, Non-Financial Incentives, Performance

\section{Background}

The emergence of human resource as a key discipline and a separate philosophy has made the modern time organization realized that employee performance is one of the keys to organizational success. Hameed and Waheed (2011), argued that the organizations are now increasing their commitments with employees, consequently enhancing the organizational and employee performance (1). They have continued and argued that the employee performance has become the matter of grave concern. The organizations are using different tools such as rewards to enhance the performance of the employee. Meanwhile, employee motivation has also emerged as an antecedent of employee performance. An organization success in driving its strategic objectives rests with the ability of its employees to drive maximum performance.

From the perspective of the employees, work performance is important because there is the constant need for employees to upgrade their standards of living. It is very important for people to improve their quality of life. This is because the quality of life is related with the lifestyle and characteristics of the employee. Spargaren and VanVliet (2000), submitted that lifestyle is basically related to the attitudes of the individuals, mode of life, global view and values that will become their personal identity (2). There are aspects that will affect employee performance especially in relation to their personal objectives, needs, healthy lifestyle and their worklife balance. Every aspect will have a huge impact on the employee performance, in health, wellbeing, working environment and inhome environment.

Motivation during work is very important to people because it will help to enhance the chances to achieve the objective of the organizations. The employer should give the suitable motivation for labor that can be hypothesized and be as a key contributor to maximize the productivity among workers' (3). In other words, if the employer gives the higher motivation to workers it will bring a higher productivity with more quality (4). To maintain a level of motivation is quite hard when workers should be able deals with different environment and more challenging to employers to demand a full commitment from the employees (5). Besides pay, a common reward package in Malaysia is a bonus, pension scheme, insurance, company car, loans, subsidized meals, and share options.

Porter and Lawler (1968) have defined rewards and recognition as desirable or positively valued outcomes or returns to a person that 
are provided by himself (intrinsic) or by others (extrinsic) (6), while Reif, Newstorm and St. Loius, Jr. (1976) defined rewards and recognition as anything that employees perceive as need satisfying. It can then be further broken down into financial and non-financial (7).

Reward and recognition are believed to modify attitude and behavior. In addition, based on cognitive evaluation theory by Deci (1975) (8), recognition would lead to the prediction, engagement and enhanced feelings of competence. Individuals who do not feel recognized would result in increased perceptions of incompetence (9).

\section{Literature Review}

\subsection{Employee Performance}

Employee performance is an important part of the organization in which employee performance can determine how much the organization growth or decrease. Bernardin and Russel (1998) emphasized that performance is interpreted as the record that is created during the period of time on specified work function or activity (10). Campbell (1993) said that performance reflects the individual that is hired to complete their task and work activities that can be assessed and measured appropriately (11). The organization requires the maximum input of employee performance to achieve their target and goals and to be able to compete with their competitors (4). The successful organization relies on the performance of the employee. The university is categorized as an industry of services which satisfies their customers. In this regard, it means students are the primary goals of the university. The services of an employee to the customer means both performances are an employee is relevant to the subject matter. When employees exceed job expectation, it means they provide great service to the customer.

Most importantly, employee performance will directly affect organizational effectiveness. So also, enhance the relationship between employee development and performance. When adequate attention is given to employee development; thereafter, the employee would be satisfied with their job. As a result, it will enable them to display more commitment to their job, therefore their performance would be generally boosted. When this is achieved, organizational effectiveness is certain (12). At present, people are very crucial to the performance of the organization. Organizational planning and strategy cannot become a reality without employees` input. Thus, the success of an organization is the function of people (employee) and the system. Human capital possesses the required knowledge, competencies, and skills required to execute the plans and strategies formulated in the organization. Therefore, it is required by these organizations well acquainted with the employee and ensures that they are encouraged to achieve their full potentials (13).

Past studies have shown that for employee performance to be related to a number of factors. Career development plan, freedom, feedback to employees, evaluation of employees, good supervisory relations and learning programs, comfortable and open work environment are those factors which constitute non-monetary rewards and they have a positive impact on employee performance and attitude in the workplace (14). In support of that, a study conducted by Ajila and Abiola (2004) indicated that there existed a relationship between employees' performance and extrinsic reward, while no relationship existed between employee's performance and intrinsic rewards (15). However, the financial rewards or monetary incentives are alone not sufficient to motivate employees (16). Mahmood et al. (2016) argued that to enhance employee commitment, and perform a mix of financial and non-financial rewards (16). According to Mahmood et al. (2016)mix and balance blend of financial and non-financial rewards is mandatory to achieve the desired level of performance (16). He continued and distinguished the financial reward from the non-financial reward saying that the financial reward includes cash compensation, bonuses, salary increments etc., whereas nonmonetary rewards refer to praise, recognition and benefits (17). It also includes paid vacation, training programs, praise and promotion (18).

Good package for employee reward has been established by various past scholars to be an important factor in the organization which enhances workers' performance and thus bring about improvement to organization's productivity (16). Most employers have now realized that the existing global economic trend has made their organizations witness competitive advantage, their employee's performance is an important factor that determines the success of the organization. Employee performance not solely benefiting the organization alone, but it is as well benefits the workers themselves when it comes to their growth matters.

Several past kinds of literature has established that exists a significant relationship between employee performance and rewards (19), between organizational justice (one of which is distributive fairness) and performance of employees at work (21-22), between organizational justice and job satisfaction (23), between performance, commitment to work and organizational justice (2425 ), between employee behavior and organizational justice (24). However, lower levels of organizational justice lead to employee dissatisfaction, bitterness and even cynicism against the organization (22). This can give rise to social hatred and enmity which lead to deterioration and loss of confidence in the organization which as a result lead to deviance in the workplace.

Moreover, another study was conducted by Njanja, Maina, Kibet, and Njagi (2013) which focused on the effect of reward on employee performance recommended that further researchers should concentrate their efforts on the effect of other kinds of rewards on employees' performance (26). It also suggested that future studies should focus on ways to identify other factors that affect employees' performance. Ajila and Abiola (2004) in their own study suggested that more researches should be conducted on the influence and relationship of rewards on employee performance using many private and public organizations (15).

Boyne (2010) observed that it is important for the organizations to have information on its employee performance (27). This will enable such organization to realize whether they are deteriorating, stagnant or making improvement. Also, it enables them to adjust quickly with a view of bringing improvement to their goods and services for organizational growth and survival (27-28). Traditionally, performance assessment embedded five dimensions of performance, they are namly as thus; effectiveness, economy, efficiency, compliance and service quality. Performance is a virtual concept and therefore it is often assessed against some benchmark by emphasizing on what has been achieved in the organizations, comparing it to the budget or compliance (29).

Managing individual performance within organizations has been traditionally been centralized on performance measurement and allocation of remuneration. Good performance is perceived to be the outcome of the collaboration between motivation and individual ability. Gradually it is being recognized that an enabling environment and effective planning affect individual performance, with standards and performance goal, guidance and support from the managers and appropriate resources are all being at the central (21). 
Individual and organizational performance can be affected by human resources practices and policies. For example, for a very long time ago, job satisfaction has been considered a key to affecting commitment as well as business commitment.

The employee is an inseparable and important part of the organization. Mostly employee productivity largely depends on the competent, skilled and qualified workforce. To boost employee behavior it means improving employee performance which ultimately benefits the organization as well as the employees concerned as well (30).

Several factors have been linked to the performance in various studies. A study conducted by Mahmood (2016) found the existence of relationships between performance-based pay, career incentives, organizational benefits, and employee performance (16). $\mathrm{He}$ observed that organizations thrive through the instrumentality of people because they possess the required skills, competencies and knowledge needed for the execution of organizational planning and strategy. Hence, organizations should entrench a competitive total remuneration package that comprises of the properly-handled performance-based pay system, career incentives and various organizational benefits (31-32). Other studies conducted by Agwu (2013) (19); Sajuyigbe, Bosede and Adeyemi (2013) (20) performance-based pay relates to employee performance and other kinds of reward packages, they stated that there will be improvement in employee performance if employee perceive fairness in the conduct of organizational especially on the activities (16). However, several other researchers found a positive relationship between employee performance, job satisfaction and organizational justice (23), between employee performance and religiosity and spirituality (33). Research conducted recently by Mahmood et al., (2016) on employee engagement and employee performance found that there is a strong significant relationship between employee engagement and employee performance (16).

\subsection{Reward and Incentives System}

Every employee will give their maximum performance and commitment when their feeling or trust that on what they give or their efforts will be rewarded by the management (34). Other than that, they also agreed that another factor can influence motivation is working conditions, training and development opportunities, and job security. But, among all these factors, which can affect employee performance, the motivation that comes with rewards is the most important and most influence (34-35).

Based on Sandilyan, Mukherjee \& Miltra (2012), using reward can contribute and get more attention from individuals that can satisfy an employee's esteem and recognition needs (36). Basically, all organizations use to pay, bonuses, promotion or other types of rewards for their employees to encourage a high level of performance (37). In order to reward the employees, many factors will change such as employee's performance, employer relationship, and training and opportunity of development.

To ensure employees are always motivated, an organization must carefully set the reward system before evaluating employee's performance and then rewarding them (34-38). This is because the reward is the stronger motivator to the employees and it is very important to reward employees that give high-performance levels to maintain their performance in future.

Furthermore, according to Sandilyan, Mukherjee, \& Miltra, (2012), if the employer can maintain the motivation of employees using reward as a motivator, it will influence people's actions and related to their skills and ability to achieve important long-term goals (36). This means, if employees can show the good performance and contribute to the organizations, they feasible to get a worthy reward in return for their contribution to the organizations (36). Therefore, among the employees, they will compete for each other to get high performance and productivity and rewarded by that (39). The purpose of rewarding employees is to ensure their level of performance is increased, to make it easier to get work done and encourage employees to be more productive to help the management to achieve their goals (36). Moreover, the author also describes rewarding generally given for those doing consistently outstanding work, high performance and end their job over a period of time.

On the other hand, a reward is an important role to motivate employees that can enhance performance and growth in the organization (38-39). San \& Theen (2012) mentioned that an organization with rewards strategy and systems can make a good motivation to employees to fulfill the organization's vision (38). Besides, people not automatically come to work and eager to do a good job except they have a high motivation in themselves. According to Imran, Ahmad, Nisar, \& Ahmad, (2014) (39) there has a significant positive relationship between rewards and employees' work motivation because reward can give a strong influencing towards the employees.

In order to enhance the motivation among employees, the organization should know what factors can influence their motivation to generate a new energy for doing their job. Mahmood et al., (2016) stated, in developing countries, employees most prefer financial benefits to survive their life and the effects of reward depend on the types of rewards, how rewards are allocated and how they use the rewards to influence employees (16).

Furthermore, some of the researcher (40) also can prove the reward is directly related to employee's work motivation because there is have the positive links between these variables. Between these relationships, if the rewarding offer changes, the work motivation of employees also changed (41). For instance, the system of reward not only influence employees' motivation but also can influence the team members (19). In this regard, many researchers have said if organizations improve rewarding ways, the motivation also would get better. Benefit satisfaction often related to employee satisfaction and part of the retention tool. Most of the organization would have a differentiated benefits programmed as to attract talent and to retain talent.

\subsection{Motivation}

Motivation is an enigmatic topic in work and organizational science (42). To make employees always motivated is one of the key challenges for the employer (37). This is because motivation is the driving force that is direct to the activity that will make a person acts. Besides that, Vroom's expectancy theory stated employees tend to be more motivated when they receive something that can raise their motivation as a reward in exchange for doing the job. This is because, motivation has a different process, which can influence our behavior to achieve some specific goal (34).

Employees will get higher levels of motivation when management cares about their welfare, allowing the officers to be involved in the management process will also increase the positive relationship between the employee and the management (43). In this research also author discuss generally, the concept of the motivation is defined as a composition of powers and mechanism which, it will help to direct human behavior in the desired manner. On the other hand, Bhola \& Raskar (2013) simplified a higher motivation will 
bring higher productivity (43). He continued and argued there is a positive relationship between reward and motivation to increase the productivity and commitment of employees.

To keep motivation level is increasing or maintains among the employee, the leaders have the responsible for this thing. This is because, according to the Sandilyan, Mukherjee and Miltra (2012), one of the main functions of the employer or leaders is to keep their employees or followers satisfied with their jobs and need to know how they can continue motivation of their employees (36). Moreover, they also can put forward organizational goals to the personal goals to ensure the productivity increase directed from personal goals to organizational goals if employees are motivated towards their work (44). Besides that, if perpetuated motivation among the employees, it also can retain and indirectly can minimize turnover among the employees. In addition, work motivation not just affect the individual but also the whole organizations. So, it is important to offer a good remuneration and composition system as a way to motivate them (45).

Normally, in organizations will evaluate the performance to allocate rewards and directly will increase the individual and also work motivation (Gohari et.al. 2013). It will start with acknowledging the planning to ensure motivation can bring the critical effect on organizational performance. If an organization wants to improve the performance and be more successful, trust plays a significant role to enhance the work motivation among the employees (43). The theory that is most related to the motivation is Herzberg Theory that has important factors to the models provided by Maslow and Porter. The researcher used this theory in this study because of this theory as one of the major theories on motivation factors which include practical and theoretical consequences. Herzberg's two-factor theory includes hygiene and motivation factors, which is shown to be effective on the improvements in term of the employees' performance. Hygiene factors are necessary to ensure the employee is not unhappy and dissatisfied with their work. Furthermore, Herzberg et al. (1959) also mentioned the perspectives of physiological needs that are financial elements or money and psychological needs to improve and grow their performance (45). If managers or leaders apply this theory, they can set apart the employee from dissatisfaction and can provide rewards and recognition to make employees satisfied with their work (45).

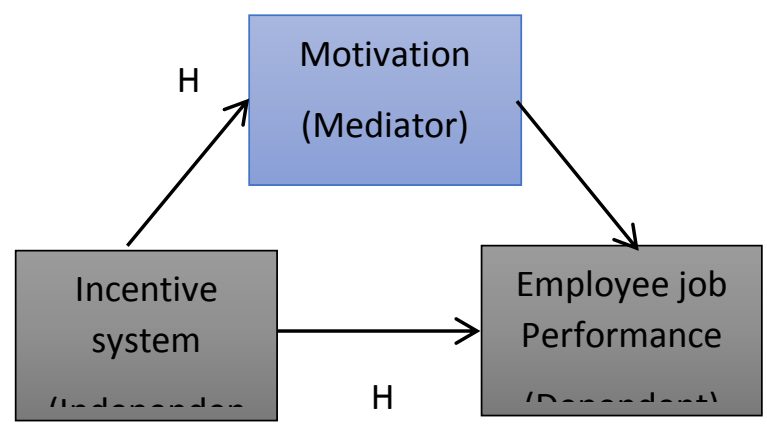

Fig. 1: The mediation model (Recruitment Process, Employee's commitment, and Organizational Performance)

H1: There is a significant positive relationship between Incentive system and Employee job Performance Employees working in Public organizations of UAE
H2: There is a significant positive relationship between Incentive system and Motivation of Employees working in Public organizations of UAE

H3: There is a significant positive relationship between Motivation and Employee job Performance Employees working in Public organizations of UAE

H4: The Employee's Motivation Mediates the relationship between relationship Incentive system and Employee job Performance of Employees working in Fujairah National Group of UAE.

\section{Data Collection Procedure}

The data of the current study is collected from the employees of public office holders of UAE via mail survey and face to face interaction. The detailed instruction was provided by the resource person to the respondents regarding the filling of the questionnaire. To ensure that the questionnaire is properly filled they were checked, in front of respondents. The response rate is 54 percent

\section{Results and Discussion}

The model of the study has undergone the model fit and confirmatory factor analysis. The item with the loading of less than 0.60 is dropped from the final analysis. The value of chi-square is 93.810 , and the value of the degree of freedom 65 , which indicating the fact that the CMN/DF value of 1.55 is acceptable. The values of model fit indices CFI (0.97),GFI (0.950), PCLOSE (0.741), and RMSEA (0.047) is above the threshold values and indicates a good model fit.

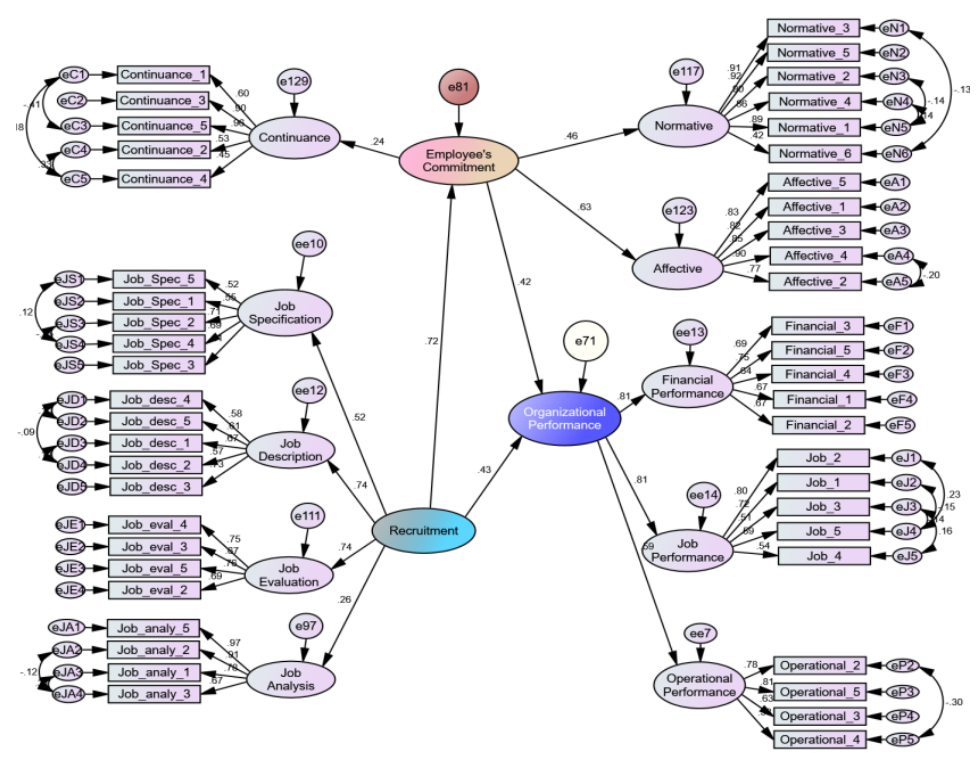

Fig 2: Amos Output

The results from SEM analysis showed a strong association between the three variables (incentives system, motivation, and job performance). All correlation is greater than (0.3), a standard threshold for considering a significant effect between these variables, where all correlations are statistically significant $(\rho \leq$ 0.000 ) as shown in Figure 2. Moreover, the degree of interpretation $\left(\mathrm{R}^{2}\right)$ has been increased for most indicators in the final structural model as well as the latent variables incentives system, motivation, 
and job performance with their factors as shown in the regression table. The following table shows the magnitudes of standard regression between these three variables:

Table 4.1: Standardized and unstandardized regressions of the structural model

\begin{tabular}{|l|c|c|c|}
\hline \multicolumn{1}{|c|}{ Relationship } & $\begin{array}{c}\text { Standardized } \\
\text { Regression }\end{array}$ & $\begin{array}{c}\text { Unstandardized } \\
\text { regression (B) }\end{array}$ & $\begin{array}{c}\text { Sig. } \\
\mathbf{\rho} \\
\mathbf{0 . 0 5}\end{array}$ \\
\hline $\begin{array}{l}\text { Incentives system -- } \\
\text {-> job performance }\end{array}$ & 0.353 & 0.254 & 0.000 \\
\hline $\begin{array}{l}\text { Incentives system -- } \\
->\text { motivation }\end{array}$ & 0.715 & 0.584 & 0.028 \\
\hline $\begin{array}{l}\text { Motivation ---> job } \\
\text { performance }\end{array}$ & 0.693 & 0.609 & 0.000 \\
\hline
\end{tabular}

It is found the highest degree of correlation between Incentives system and motivation. Reading the magnitude of path estimate between them $\beta=0.715$. All correlations confirm a good degree of association between the variables.

Hypothesis 1 predicted a positive correlation between incentives system and job performance. To derive the overall influence of job performance association on incentives system, the researcher analyzed the critical ratio (C.R) value of > 1.96 and is used to indicate a statistically significant correlation between them. It is found that job performance correlates significantly with the incentives system because C.R value $=2.195 \geq 1.96$. Furthermore, C.R positive value is statistically insignificant $(\rho \leq 0.000$, Sig. $\leq$ 0.05 ), this result suggests a positive correlation and association between incentives system and job performance. Thus, the alternative hypothesis $\mathrm{H}_{\mathrm{a} 1}$ is true and the null-hypothesis $\mathrm{H}_{01}$ is not true (rejected and not supported).

Hypothesis 2 predicted a positive correlation between incentives system and motivation. To derive the overall influence of incentives system on motivations, the researcher analyzed the critical ratio (C.R) value of $>1.96$ and is used to indicate a statistically significant correlation between Functionality and incentives system of SIS. It is found that motivations correlate significantly with incentives system because $C . R$ value $=4.872 \geq 1.96$. Furthermore, C.R positive value is statistically significant $(\rho \leq 0.000$, Sig. $\leq 0.05)$, this result suggests a positive correlation and association between motivations and incentives system. Thus, the alternative hypothesis $\mathrm{H}_{22}$ is true and the null-hypothesis $\mathrm{H}_{02}$ is not true (rejected and not supported).

Hypothesis 3 predicted a positive correlation between motivations and job performance. To derive the overall influence of motivations on job performance, the researcher analyzed the critical ratio (C.R) value of $>1.96$ and is used to indicate a statistically significant correlation between motivations and job performance. It is found that C.R positive value is statistically insignificant $=3.318 \geq 1.96$ ( $\rho$ $\leq 0.000$, Sig. $\leq 0.05$ ), this result suggests a positive correlation and association between motivations and job performance. Thus, the alternative hypothesis $\mathrm{H}_{\mathrm{a} 3}$ is true and the null-hypothesis $\mathrm{H}_{03}$ is not true (rejected and not supported).

Table 4.2: Outputs of mediation test

\begin{tabular}{|c|c|c|c|c|c|c|}
\hline DV & $\mathbf{M}$ & $\mathbf{D V}$ & $\mathbf{A}$ & $\mathbf{a}^{\prime}$ & $\mathbf{b}$ & $\mathbf{C}$ \\
\hline $\begin{array}{c}\text { Job } \\
\text { Performa } \\
\text { nce }\end{array}$ & $\begin{array}{c}\text { Motivati } \\
\text { ons }\end{array}$ & $\begin{array}{c}\text { Invent } \\
\text { ive }\end{array}$ & 0.860 & 0.353 & 0.584 & 0.609 \\
\hline & & & $\begin{array}{c}\text { Sig. }=0 . \\
000\end{array}$ & $\begin{array}{c}\text { Sig. }=0 . \\
028\end{array}$ & $\begin{array}{c}\text { Sig. }=0 . \\
000\end{array}$ & $\begin{array}{c}\text { Sig. }=0 . \\
004\end{array}$ \\
\hline
\end{tabular}

The mediation test is of employee commitment in the relationship between recruitment process and organizational performance is carried out following Baron and Kenny's (1986) (46). The value
0.353 indicates that employee commitment offers a partial mediation between recruitment process and organizational performance.

\section{Conclusion}

The outcome of the empirical analysis shows that incentives consist of three factors. The first factor is non-monetary incentives. It is found that the encouragement in work from managers motivates the employees to give better performance, the staff believes that the premium nature of work or risk encourages them to perform better but the employees are feeling secure and stable because of the retirement system at the of their service. It is found that the moral incentives are not less important than financial incentives; the employees agreed that the organizations should provide moral incentives for all employees who show good performance. However, the staffs are not sure whether receiving appreciations from the managers for in work, the certificate of appreciation is important to motivate employees in any organization.

The second factor is monetary or financial incentives. The responses of participants in the survey reveal that the salary fills the basic needs of employees and bonus system is somehow fair. It is evident the current bonus system is not satisfactory because the majority of respondents want to improve the bonuses system to add to my salary annually as well as the corresponding salary for employees drives them to improve their performance. Thus, the organization must give fair bonuses to employees also the organization needs to adopt a better system for incentives. In general, there is a general dissatisfaction with the current incentives system in the organization. The last factor of incentives is the Social Dimension. The staffs believe that the government incentive system is good and works to improve the performance of employees and the retirement law of U.A.E is fair, and one of the important findings is that the salary provides social guarantees to the employees and they feel that the social allowances for the wife and children are acceptable in U.A.E. Despite the jobs in U.A.E provide average incentives and benefits; most employees are looking forward to getting better salary. Even though, the government of U.A.E provides a fair health insurance and appropriate services to the employees.

The analysis in chapter four reveals that motivation can be measured in three factors (intrinsic, extrinsic, and behavior). The first factor is intrinsic. It is found that the employees agree the promotion mechanisms in the government incentive system are appropriate and they suggest that the granting of career promotions has a positive impact on job performance. But there are few promotions based on efficiency and performance which reflects a negative sign of the current promotion system in the organization. Thus, employees want to change their career through competitions. There is a correlation between an employee's qualifications and experience and his/her degree. The employees believe that promotions based on the ministerial structure have contributed to the development of performance. The second factor is extrinsic. The employees believe that the reward system in the Incentive Act of U.A.E needs further improvement because employees confirm they rarely receive a reward for outstanding performance. The Direct Manager must recommend exceptional bonuses to his or her competent staff as well. Because of this, the respondents believe that the government reward system should promote better job performance.

Furthermore, the employees in this organization assure that lack of knowledge on how the incentives system and its mechanisms work. Bonuses are not distributed to those who deserve them. Behaviour is the third factor of motivations. It is found the employees are not satisfied because the managers and supervisors in this organization have been promoted fairly but the employees are not. The majority 
of career promotions give us merit and perseverance at work. Despite that, the employees believe that the system of outstanding promotions helps to improve the behavior of employees. But promotions by means of favoritism have a negative impact on their performance career. According to that, this study suggests granting bonuses should be given to those who show loyalty to the organization and give a high degree of performance. Finally, the employees are not sure that the immediate manager appreciates and appreciates their efforts at work. The empirical findings of this study show that motivation of employees plays a mediator role in the association between incentives system and job performance. A partial mediation relationship is occurred due to the indirect effect of motivations (mediator) on this relationship.

The empirical finding of this study indicates that job performance can be measured of three factors (skills, knowledge, and productivity). The skills of an employee are a very important measurement. The respondents predict that the results of the annual performance assessment are the basic criteria for granting incentives and rewards. They believe that managers are interested in the results of the annual performance evaluation on the basis that it is a standard for reward and punishment. They have adequate skill to fulfill the tasks of my work (and the senior management of the ministry associates the promotion grants with skills and ability to do the work, but employees need for training to improve their skills in work.

Furthermore, they are interested in the results of my annual performance appraisal because it is considered an opportunity to receive rewards. With regard to knowledge of employees, the second measurement of job performance, it is found that employees are satisfied with their current information on the work and they see that those who fail to perform in their duties are punished by assessing their knowledge on the work. Thus, the organization must test employees' knowledge on the type of work on a regular basis in order that employees have adequate information to do complex tasks.

The result indicates that employees in this organization are capable to learn new details about their work, but training is still necessary for employees to enhance their knowledge of the work. Productivity is the third factor of job performance. Employees believe that the annual performance report is the main tool for granting incentives and rewards and they find that the results of the positive performance evaluation motivate and drive them to work efficiently. Accordingly, the employees can give better performance if get training. Many employees complain about doing unnecessary duties despite they are able to schedule their tasks in the work. Therefore, this organization needs to enhance the productivity of employees through motivations and adopting efficient incentives system.

Job performance is the dependent variable in this study. It is found that the incentives system is a strong predictor of job performance. It is possible to develop the performance of employees in the workplace through efficient incentivizes and strong motivation. The empirical finding of this study reveals a positive correlation and association between incentives system and job performance as well as between motivations and job performance.

\section{References}

[1] Hameed, A., \& Waheed, A. (2011). Employee development and its effect on employee performance a conceptual framework. International journal of business and social science, 2(13).
[2] Spaargaren, G., \& Van Vliet, B. (2000). Lifestyles, consumption and the environment: The ecological modernization of domestic consumption. Environmental politics, 9(1), 50-76.

[3] Kalburgi, M. J. Dinesh. GP (2010). Motivation as a tool for productivity in a Public sector unit. Astan Journal of Management Research, 147-152.

[4] Rahim, M. A., \& Daud, W. N. W. (2013). Rewards and motivation among administrators of Universiti Sultan Zainal Abidin (UNISZA): An empirical study. International Journal of Business and Society, 14(2), 265.

[5] Tella, A., Ayeni, C. O., \& Popoola, S. O. (2007). Work motivation, job satisfaction, and organizational commitment of library personnel in academic and research libraries in Oyo State, Nigeria. Library Philosophy and Practice (e-journal), 118.

[6] Porter, L. W., \& Lawler, E. E. (1968). Managerial attitudes and performance.

[7] Reif, W. E., Newstrom, J. W., \& St. Louis Jr, R. D. (1976). Sex as a discriminating variable in organizational reward decisions. Academy of Management Journal, 19(3), 469-476.

[8] Deci, E. L. (1976). Notes on the theory and metatheory of intrinsic motivation. Organizational behavior and human performance, 15(1), 130-145.

[9] Shanab, M. E., Peterson, D., Dargahi, S., \& Deroian, P. (1981). The effects of positive and negative verbal feedback on the intrinsic motivation of male and female subjects. The Journal of Social Psychology, 115(2), 195-205.

[10] Bernardin, H. J., \& Russel, J. E. (1998). Human Management.

[11] Campbell, I. (1993). Thomas Carlyle. Hyperion Books.

[12] Champathes, M. R. (2006). Coaching for performance improvement: The "Coach" model. Development and Learning in Organizations: An International Journal, 20(2), 17-18.

[13] Lawler, E. E. (2003). Reward practices and performance management system effectiveness. Organizational Dynamics, 32(4), 396-404.

[14] Bari, N., Arif, U., \& Shoaib, A. (2013). Impact of non-financial rewards on employee attitude and performance ance in the workplace. A case study of Business Institute of Karachi. International Journal of Scientific \& Engineering Research, 4(7), 2554-2559.

[15] Ajila, C., \& Abiola, A. (2004). Influence of rewards on workers performance in an organization. Journal of Social Sciences, 8(1), 712.

[16] Mahmood, A., Hussan, S. G., Sarfraz, M., Abdullah, M. I., \& Basheer, M. F. (2016). Rewards Satisfaction, Perception about Social Status and Commitment of Nurses in Pakistan. European Online Journal of Natural and Social Sciences, 5(4), pp-1049.

[17] Luthans, F., Norman, S. M., Avolio, B. J., \& Avey, J. B. (2008). The mediating role of psychological capital in the supportive organizational climate-employee performance relationship. Journal of Organizational Behavior: The International Journal of Industrial, Occupational and Organizational Psychology and Behavior,29(2), 219-238.

[18] Basheer, M. F (2017). Empowering women through micro finance: a case of Pakistan.

[19] Agwu, M. O. (2013). Impact of fair reward system on employees"e job performance in Nigerian Agip Oil Company Limited, Port Harcourt. British Journal of Education, Society and Behavioral Science, 3(1), 47-64.

[20] Sajuyigbe, A. S., Olaoye, B. O., \& Adeyemi, M. A. (2013). Impact of reward on employees performance in a selected manufacturing company in Ibadan, Oyo state, Nigeria. International Journal of Arts and Commerce, 2(2), 27-32.

[21] Alder, G. S., \& Tompkins, P. K. (1997). Electronic performance monitoring: An organizational justice and conservative control perspective. Management Communication Quarterly, 10(3), 259-288.

[22] Basheer, M. F., Hussain, T., Hussan, S. G., \& Javed, M. (2015). Impact of customer awareness, competition and interest rate on the growth of Islamic banking in Pakistan. International Journal of Scientific \& Technology Research, 4(8), 33-40.

[23] Cropanzano, R., Bowen, D. E., \& Gilliland, S. W. (2007). The management of organizational justice. Academy of management perspectives, 21(4), 34-48.

[24] Rupp, D. E., Shapiro, D. L., Folger, R., Skarlicki, D. P., \& Shao, R. (2017). A critical analysis of the conceptualization and measurement 
of organizational justice: Is it time for reassessment?. Academy of Management Annals, 11(2), 919-959.

[25] Basheer, M. F., KhorramI, A. A. A., \& Hassan, S. G. (2018). PATRONAGE FACTORS OF ISLAMIC BANKING SYSTEM IN PAKISTAN. Academy of Accounting and Financial Studies Journal, 22, 1-9.

[26] Njanja, L. W., Maina, R. N., Kibet, L. K., \& Njagi, K. (2013). Effect of reward on employee performance: A case of Kenya Power and Lighting Company Ltd., Nakuru, Kenya. International Journal of Business and Management, 8(21), 41.

[27] Boyne, G. A. (2010). Performance management: Does it work. Public management and performance: Research directions, 207-226.

[28] Basheer, M. F., KhorramI, A. A. A., \& Hassan, S. G. (2018). Patronage factors of Islamic banking system in Pakistan. Academy of Accounting and Financial Studies Journal, 22, 1-9.

[29] Carin, B., \& Good, D. A. (2004, July). Evaluating efficiency and effectiveness in public sector delivery. In Proceedings Kaliningrad Workshop, July (pp. 24-25).

[30] Rounok, N., \& Parvin, M. M. (2011). Fostering Employee Performance: A Literature Review. Industrial Engineering Letters, 1(3), 1-9.

[31] Samander, B. A., Siam, M. R., Basri, W. S., \& Hamed, A. A. (2017). ERP Acceptance in Airline Industry of Saudi Arabia with Mediating Effect of Job Security. International Journal, 11(2), 226-240.

[32] Siam, M. R. (2015). The effect of communication strategy on the relationship between strategy execution and organizational performance: A middle-level managers perspective on higher education institutions in Palestine (Doctoral dissertation, Universiti Utara Malaysia).

[33] Osman-Gani, A. M., Hashim, J., \& Ismail, Y. (2013). Establishing linkages between religiosity and spirituality on employee performance. Employee relations, 35(4), 360-376.

[34] Hafiza, N. S., Shah, S. S., Jamsheed, H., \& Zaman, K. (2011). The relationship between rewards and employee's motivation in the nonprofit organizations of Pakistan. Business Intelligence Journal, 4(2), 327-334.

[35] Basheer, M. F., Nadeem, S., Azeem, M., \& Mahmood, A. Impact of customer satisfaction on brand equity under the influence of brand trust.

[36] Sandilyan, P., Dey, A., Mukherjee, M., \& Mitra, M. Determining Employee Commitment By Employee's Responses On Training And Development-A Study Of Select Hotels In West Bengal. Excel, 16(32), 125.

[37] Ahmed, A. U. H., Ali, R., Zamir, S. I., \& Mehmood, N. (2009). Growth, yield and quality performance of cotton cultivar BH-160 (Gossypium hirsutum L.). J. Anim. Plant Sci, 19(4), 189-192.

[38] San, O., Theen, Y., \& Heng, T. (2012). The reward strategy and performance measurement (evidence from Malaysian insurance companies). International Journal of Business, Humanities and Technology, 2(1), 211-223.

[39] Imran, A., Ahmad, S., Nisar, Q. A., \& Ahmad, U. (2014). Exploring relationship among rewards, recognition and employees' job satisfaction: A descriptive study on libraries in Pakistan. Middle-East Journal of Scientific Research, 21(9), 1533-1540.

[40] Basheer, M., Ahmad, A., \& Hassan, S. (2019). Impact of economic and financial factors on tax revenue: Evidence from the Middle East countries. Accounting, 5(2), 53-60.

[41] Javed, M. A., \& Basheer, M. F. (2017). Impact of external factors on bank profitability. EPRA International Journal of Research and Development, 2(5), 1-11.

[42] Kanfer, R., Chen, G., \& Pritchard, R. D. (2008). The three C's of work motivation: Content, context, and change. Work motivation: Past, present, and future. New York: Routledge, Taylor \& Francis Group.

[43] The Bhola, S. S., \& Raskar, S. (2013). A Comparative Assessment of Employee's Perception towards Motivational Practices of Engineering Industry in Satara.

[44] Muogbo, U. S. (2013). The impact of strategic management on organisational growth and development (A study of selected manufacturing firms in Anambra state). IOSR Journal of Business and Management, 7(1), 24-32.

[45] Herzberg, F. M., \& Mausner, B. (1959). B. \& Snyderman, B.(1959). The motivation to work, 2.
[46] Baron, R. M., \& Kenny, D. A. (1986). The moderator-mediator variable distinction in social psychological research: Conceptual, strategic, and statistical considerations. Journal of personality and social psychology, 51(6), 1173. 